\title{
Culture Mixed-Sex and Monosex of Tilapia in Ponds in Mexico City
}

\author{
Jose Luis Gómez-Márquez ${ }^{1}$, Bertha Peña-Mendoza ${ }^{1}$, María del Carmen Alejo-Plata², \\ José Luis Guzmán-Santiago ${ }^{1}$ \\ ${ }^{1}$ Laboratorio de Limnología, Facultad de Estudios Superiores Zaragoza, Universidad Nacional Autónoma de \\ México, México, D.F., México \\ ${ }^{2}$ Campus Puerto Ángel, Universidad del Mar, Ciudad Universitaria, Puerto Ángel, México \\ Email: Igomez@unam.mx
}

Received 15 January 2015; accepted 1 February 2015; published 3 February 2015

Copyright (C) 2015 by authors and Scientific Research Publishing Inc.

This work is licensed under the Creative Commons Attribution International License (CC BY).

http://creativecommons.org/licenses/by/4.0/

(c) (i) Open Access

\section{Abstract}

In this study, the growth of Oreochromis niloticus both mixed sex and males sexually reversed were analyzed in concrete ponds in the FES Zaragoza, UNAM, under the environmental conditions of the Mexico City. The experiment was carried from May to November 2013, in two concrete ponds of $50 \mathrm{~m}^{2}$. Similar feeding regime and stocking density of fish were maintained for the culture systems. Different growth parameters like body weight, length, daily weight gain (DWG), specific growth rate (SGR), feed conversion rate (FCR), Fulton's condition index (K) and survival were analyzed during six months culture period. It was found that culture with monosex males tilapias yielded the highest weight, length, DWG and SGR compared to mixed sex populations tilapias. Water quality was monitored along the experiment. Based on the results, there were statistically significant differences in size $(W=20942.5, p<0.05)$ and weight $(W=21413.0, p<0.05)$ between the divisions of the pond. The initial total length used was $1.2 \mathrm{~cm}$ and ended with $20.4 \mathrm{~cm}$ for monosex males, higher than mixed-sex population. The initial average body weight of the fish was $0.21 \mathrm{~g}$ and they recorded $192.2 \mathrm{~g}$ at the end of culture for monosex males. The weight-length relationship for both populations of fish was positive allometric. The percentage gain in body weight and total length averaged were $150 \%$ and $31.8 \%$ respectively. Specific growth rates in weight and length for monosex males were higher than mixed-sex population. Daily weight gain and size was similar in both populations. The FCR had a mean value of 1.9:1 for monosex males and condition factor $(\mathrm{K})$ had an average of 1.45 for mixed-sex population. Water quality indicated good oxygenation $(>5 \mathrm{mg} / \mathrm{L})$, warm water $\left(>20^{\circ} \mathrm{C}\right)$, productive $\left.(<100 \mathrm{mg} / \mathrm{L} \mathrm{CaCO})_{3}\right)$ and slightly basic ( $\mathrm{pH}>8)$. Acceptable growth of fish and a yield of 3 ton/ha/ 6 months were obtained in both two ponds; therefore, the culture of tilapia under conditions of Mexico City was recommended.

\section{Keywords}

Tilapia, Culture, Growth, Survival, Mexico City

How to cite this paper: Gómez-Márquez, J.L., Peña-Mendoza, B., del Carmen Alejo-Plata, M. and Guzmán-Santiago, J.L. (2015) Culture Mixed-Sex and Monosex of Tilapia in Ponds in Mexico City. Agricultural Sciences, 6, 187-194. 


\section{Introduction}

The Nile tilapia, Oreochromis niloticus (Linnaeus) is one of the most important freshwater fish in world aquaculture [1] [2]. It is widely cultured in many tropical and subtropical countries of the world [3]. Tilapias of the family Cichlidae were introduced from Africa [4] and, represent important social and economic benefits to rural communities [5].

Rapid growth rates, high tolerance to adverse environmental conditions, efficient feed conversion, ease of spawning, resistance to disease and good consumer acceptance make it a suitable fish for culture [6]-[8]. Farmed tilapia production decreased dramatically in recent years, decreasing from 92981 ton in 1993 to 75,927 ton in 2011 [9]. The major concern for tilapia aquaculture is excessive reproduction and the resulting small size of the fish produced [10]-[12]. Hence, the desirability of monosex male populations of tilapia is well established for increased production potential and low management requirements. Besides, sex-specific differences in growth are significant in Nile tilapia where males grow significantly faster, the metabolic energy is channeled towards growth larger and more uniform in size than females [13]-[15]. They benefit from anabolism enhancing androgens. In females, there is a greater reallocation of metabolic energy towards reproduction [16] [17].

Intensive monoculture of the fish in concrete tanks is carried out in a few countries [18]. The problem of overpopulation in ponds caused by uncontrolled reproduction is a major constraint to the further development of the tilapia culture industry. One solution to this problem is the use of monosex male populations which can be produced by a number of means [18]-[20]. One method commonly used in developed countries and increasingly gaining acceptance in developing countries is the culture of all-male fish produced by the oral administration of 17a-methyltestosterone (MT) during the period of gonadal differentiation of the fish [20] [21]. Then, the aim was to evaluate and to compare the performance of mixed-sex and monosex stocks of Nile tilapia in Mexico City, in outdoor fertilized concrete ponds with available natural and supplementary food.

\section{Material and Methods}

\subsection{Experimental Fish and Feeding Trial}

Nile Tilapia fingerlings (O. niloticus) were obtained from Aquaculture Production Center Zacatepec, Morelos belongs to CONAPESCA, Mexico. Tilapia fingerlings were transported in plastic bags filled with hatchery pond water and filled with air and transported to Experimental Aquaculture Unit at FES Zaragoza of the National Autonomous University of Mexico, in Mexico City where this experiment was realized. The batch of tilapia stocked in May has been over-wintered. Two concrete ponds were used for stocking of tilapia, in one with monosex male and other with mixed-sex populations stock, with a surface area of $50 \mathrm{~m}^{2}$ and water depth of $0.75 \mathrm{~m}$.

Initially, 650 fish fingerlings were introduced in 1000-L circular tank and maintained during 40 days before start the experiment. During this time they were fed with steelhead rainbow trout commercial feed $(41.9 \% \pm$ $0.13 \%$ of protein and $12.08 \% \pm 0.12 \%$ of lipids). The acclimated fish (mean initial body weight $0.2 \pm 0.05 \mathrm{~g}$ ) were placed into two concrete ponds. Three hundred fingerlings (six fish $\left./ \mathrm{m}^{2}\right)$ were randomly distributed in each pond. Fish were fed with commercial steelhead rainbow trout feed for 180 days (May to November 2013) at the rate of $6 \%$ of their body weight for the first thirty days then gradually reduced to $3 \%$ for remaining days. The daily ration was given in three equal proportions at 10:00, 14:00 and 18:00 h, respectively. At the beginning of the experiment and every 30 days, 40 fish fry was individually were measured for total length (TL) and standard length (SL) to the nearest $0.1 \mathrm{~cm}$ and weighed (body weight, BW) to the nearest $0.1 \mathrm{~g}$. Water quality was monitored along the experiment and in situ measurements were taken for environmental variables such as: water temperature and dissolved oxygen (DO) with a water oximeter using Hanna portable (model HI9146); transparency with a Secchi disk. Conductivity, $\mathrm{pH}$ and total dissolved solids were measured in-situ using Hanna portable combo waterproof pH/EC/TDS/Temperature Tester, model HI 991300. Total alkalinity, total harness and ammonia-nitrogen were determined in the laboratory according to [22] [23] procedures.

\subsection{Growth Performance and Fed Efficiency}

The following indicators were calculated: Initial Body Weight (IBW); Final Body Weight (FBW); Initial Total Length (ITL); Final Total Length (FTL); Daily Weight Gain (DWG); Daily Size Gain (DSG); Specific Growth Rate (SGR in \%/day) $=100 \times(\mathrm{Ln}$ final weight $(\mathrm{g})-\mathrm{Ln}$ initial weight (g)/days of the experiment); Feed Conversion Rate (FCR) = feed intake (g)/weight gain (g); Feed Efficiency (FE) = weight gain (g)/Feed intake (g); Ful- 
ton's condition index $(\mathrm{K})=\left(\right.$ body weight/total length $\left.{ }^{\mathrm{b}}\right) \times 100$ and \% survival, according with [18] [24] [25].

The total length (TL)-total body weight (BW) relationship was calculated by a power regression between these variables for each sex using the formula:

$$
\mathrm{BW}=\mathrm{aTL}
$$

where BW is the body weight, TL the total length, $b$ the growth exponent or length-weigh factor, and $a$ is a constant. The values of a and b were estimated by means of a "linearized" form of that equation by taking (base 10) logarithms on both sides and estimating the values of $\log$ (a) and $\log$ (b) by means of a linear regression, using ordinary least-squares regression. Student's $t$ test was used to accept (or reject) the hypothesis of isometric growth [26].

\section{Statistical Analysis}

Data were subjected to analyses of U-Mann-Whitney and Kruskal-Wallis [27] [28] in order to determine significant differences on fish performance ( $\mathrm{p}<0.05)$, using the statistical program SPSS Version 15.0 (SPSS, Michigan Avenue, Chicago, IL, USA).

\section{Results}

\subsection{Water Quality Parameters}

The physical and chemical parameters of ponds water take every third day during the experiment (Table 1) were maintained within the tolerance range of Nile tilapia. The water mean value temperature obtained in the experiment was of $21^{\circ} \mathrm{C} \pm 0.1^{\circ} \mathrm{C}$. There were not statistical differences between both ponds ( $\mathrm{W}=46.5 ; \mathrm{p}=0.147$ ), but a statistical difference was registered in the water temperature among the months $(H=17.6 ; p=0.045)$. Secchi disc transparency with a mean value of $0.32 \pm 0.05 \mathrm{~m}$ was obtained during the study. There were no significant differences for Secchi disk depth between ponds $(\mathrm{W}=72$; $\mathrm{p}=0.975)$. Dissolved oxygen fluctuated between lowest of $5.2 \pm 0.7 \mathrm{mg} / \mathrm{L}$ obtained in August 2013 by mixed-sex populations and the highest of $10.3 \pm 0.25$ $\mathrm{mg} / \mathrm{L}$ recorded in June in the monosex male tilapia. There was not statistical difference in the dissolved oxygen concentration between the ponds $(\mathrm{W}=49.5 ; \mathrm{p}=0.203)$, but there was difference among months $(\mathrm{H}=23$; $\mathrm{p}<$ 0.017).

The surface water $\mathrm{pH}$ fluctuated between slight to moderate alkalinity. No acidic $\mathrm{pH}$ was recorded; it was alkaline for most part of the study. The monthly mean variations in electrical conductivity and total dissolved solids (TDS) followed similar trend with increase to end of period. There were variation in conductivity and TDS during the study. Both electrical conductivity and TDS showed significant differences in their concentrations among the months $(H=22.5 ; p=0.20)$, but there was not between ponds $(\mathrm{W}=76 ; \mathrm{p}=0.839)$. The range of the total hardness was of $35.8 \mathrm{mg} \mathrm{CaCO} / \mathrm{L}$ to $98.2 \mathrm{mg} \mathrm{CaCO} / \mathrm{L}$. Total ammonia nitrogen concentration was lowest at $0.1 \pm 0.05 \mathrm{mg} / \mathrm{L}$ at the beginning of the study (May), it gradually increased until a maximum concentration of $0.39 \pm 0.1 \mathrm{mg} / \mathrm{L}$ in September. There was not statistical different between ponds $(\mathrm{W}=65 ; \mathrm{p}=0.706)$.

Table 1. Data of physical and chemical parameters of the water in concrete ponds for Nile tilapia monosex male and mixedsex culture (mean values \pm s.e.) from May to November 2013.

\begin{tabular}{ccccc}
\hline & \multicolumn{2}{c}{ Monosex male } & \multicolumn{2}{c}{ Mixed-sex population } \\
\hline Parameters & Means of parameters & Range of parameters & Means of parameters & Range of parameters \\
\hline Water temperature $\left({ }^{\circ} \mathrm{C}\right)$ & $20.9 \pm 0.5$ & $17.7-24.2$ & $21.6 \pm 0.6$ & $17.5-25$ \\
Dissolved oxygen $(\mathrm{mg} / \mathrm{L})$ & $10.3 \pm 0.25$ & $6.3-16.6$ & $7.27 \pm 0.7$ & $5.2-9.9$ \\
$\mathrm{pH}$ & $9.5 \pm 0.2$ & $8.1-10.6$ & $9.1 \pm 0.2$ & $7.8-10.4$ \\
Secchi disk $(\mathrm{m})$ & $0.35 \pm 0.05$ & $0.30-0.40$ & $0.30 \pm 0.1$ & $0.25-0.35$ \\
Total hardness $(\mathrm{mg} \mathrm{CaCO} / \mathrm{L})$ & $92 \pm 5$ & $45-120$ & $68 \pm 9$ & $36-98$ \\
Conductivity $(\mu \mathrm{S} / \mathrm{cm})$ & $890 \pm 25$ & $749-1145$ & $856 \pm 40$ & $750-1250$ \\
Total Dissolved Solids $(\mathrm{mg} / \mathrm{L})$ & $725 \pm 14$ & $520-952$ & $655 \pm 25$ & $456-998$ \\
Alkalinity $(\mathrm{mg} \mathrm{CaCO} / \mathrm{L})$ & $108 \pm 15$ & $73-135$ & $92 \pm 19$ & $55-140$ \\
Ammonia $(\mathrm{mg} / \mathrm{L})$ & $0.28 \pm 0.15$ & $0.12-0.55$ & $0.33 \pm 0.1$ & $0.28-0.39$ \\
\hline
\end{tabular}




\subsection{Growth Performance}

The tilapia fish maintained a trend of weight increase along the 180 days trial. However, higher increase was observed at 150 days with the commercial feed utilized. FBW, FE, DWG, FCR and K (Table 2) of fish were significantly affected and improved by protein level of the food and possibly by the water temperature range. It is important mentioned that the mean DWG of fish in all treatment ranged from 0.10 to $0.99 \mathrm{~g} /$ day (Table 2) and the FBW is considerate very good in those concrete ponds in the Mexico City.

The survival percentage in all the culture was around 95\%, the lower mortality was registered in June, probably by the manipulation realized to the fish. Total sample size of $O$. niloticus was 292 individuals in each pond of $50 \mathrm{~m}^{2}$ during 180 days. Total length and body weight ranged from 2.2 to $19.8 \mathrm{~cm}$ and 0.2 to $131.7 \mathrm{~g}$ respectively for mixed-sex population tilapia. In monosex males tilapia, the total length and body weight ranged from 1.2 to $20.4 \mathrm{~cm}$ and 0.11 to 192.2 g respectively (Figure 1 ). The total length $(\mathrm{W}=20942.5, \mathrm{p}<0.05$ ) and body weight $(\mathrm{W}=21413.0, \mathrm{p}<0.05)$ did differs significantly between ponds.

Length-weight relationship was calculated for both populations and these equations are given as follow:

$$
\begin{gathered}
\mathrm{BW}=0.013 \mathrm{TL}^{3.136}, \mathrm{r}^{2}=0.990 ; \mathrm{p}=3.333 \mathrm{E}-187 \text { for monosex males tilapia } \\
\mathrm{BW}=0.016 \mathrm{TL}^{3.006}, \mathrm{r}^{2}=0.979 ; \mathrm{p}=1.005 \mathrm{E}-171 \text { for mixed }- \text { sex population tilapia }
\end{gathered}
$$

Weight increases allometrically with size (Figure 2) since the b value was significantly different than 3

Table 2. Data of stocking and harvest parameters of monosex male and mixed-sex Nile tilapia in concrete ponds (mean values \pm s.e.) in period from May to November 2013 .

\begin{tabular}{ccccc}
\hline & \multicolumn{2}{c}{ Mixed-sex population } & \multicolumn{2}{c}{ Monosex male } \\
\hline Growth parameters & Means of parameters & Range of parameters & Means of parameters & Range of parameters \\
\hline Initial body weight (g) & $1.0 \pm 0.05$ & $0.8-1.2$ & $0.21 \pm 0.01$ & $0.11-0.36$ \\
Final body weight (g) & $74.8 \pm 10.9$ & $23.7-140.3$ & $91.3 \pm 10.4$ & $13.8-192.2$ \\
Initial total length (cm) & $4.0 \pm 0.1$ & $3.8-4.2$ & $2.4 \pm 0.07$ & $1.2-3.0$ \\
Final total length (cm) & $15.5 \pm 1.3$ & $11.0-21.3$ & $16.1 \pm 0.64$ & $9.5-20.4$ \\
SGR (\%/day) & $3.0 \pm 0.12$ & $2.0-4.7$ & $4.1 \pm 0.14$ & $0.56-8.1$ \\
DWG (g/day) & $0.52 \pm 0.15$ & $0.10-0.99$ & $0.51 \pm 0.8$ & $0.07-0.70$ \\
DSG (cm/day) & $0.11 \pm 0.05$ & $0.10-0.12$ & $0.07 \pm 0.01$ & $0.03-0.17$ \\
FCR & $1.8 \pm 0.03$ & $0.7-2.3$ & $1.97 \pm 0.07$ & $1.65-2.25$ \\
FCI (K) & $1.45 \pm 0.11$ & $1.3-1.6$ & $1.12 \pm 0.12$ & $0.76-1.75$ \\
FE & $1.03 \pm 0.09$ & $0.81-1.21$ & $0.74 \pm 0.05$ & $0.58-0.95$ \\
Survival (\%) & 97.2 & & 95 & \\
\hline
\end{tabular}

Daily Weight Gain (DWG); Daily Size Gain (DSG); Specific Growth Rate (SGR); Feed Conversion Rate (FCR) Feed Efficiency (FE); Fulton's condition index (K).

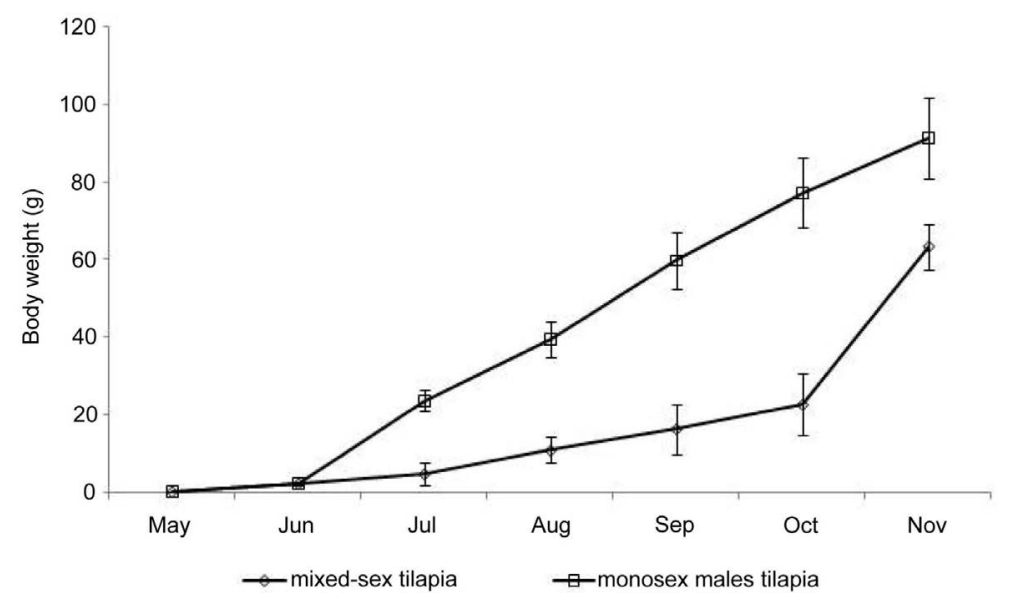

Figure 1. Growth curve of live body weight for mono-sex males and mixedsexd Oreochromis niloticus during the study period (mean \pm e.e). 

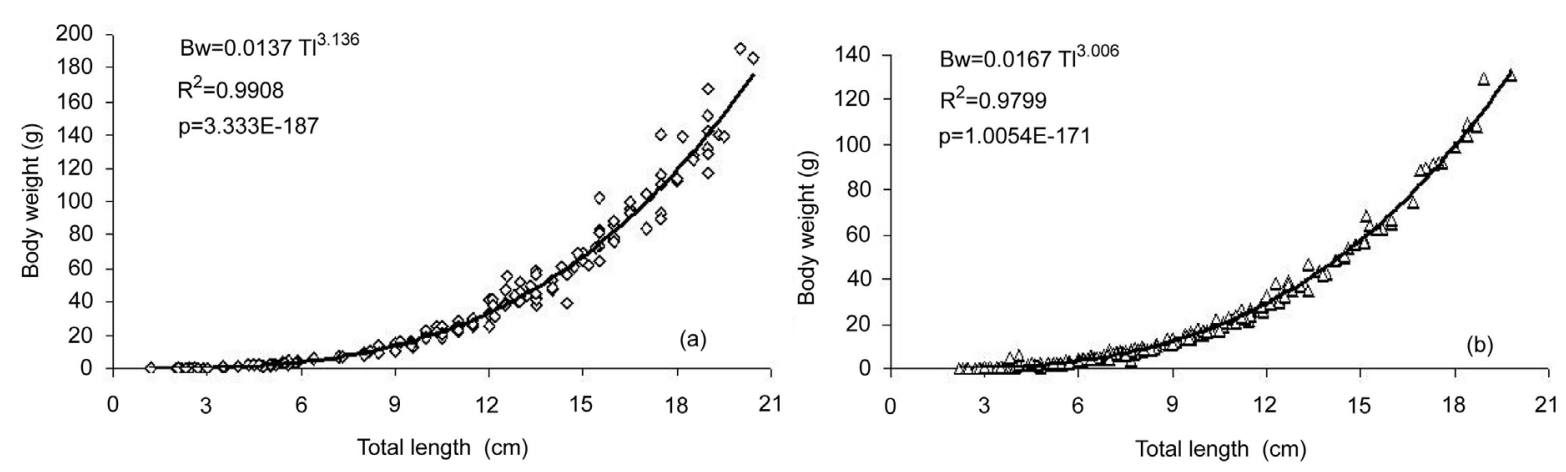

Figure 2. Length-weight relationships for (a) monosex males tilapia and (b) mixed-sex population tilapia.

$(t$-value $=4.67 ; \mathrm{p}<0.05)$.

Condition increased from May to November, this may be due to prevailing adequate environmental conditions. When the growth began in May, the condition of the males decreased; however in August the maximum condition values were achieved, as a consequence of weight increase due to the environmental conditions and food available.

\section{Discussion}

The potential role of tilapia culture in Mexico City was clearly indicated by the experiment. Analyses from the two experiments clearly indicate that increased growth rates resulted in larger adult fish yields on monosex tilapia than mixed-sex populations. Fish of strains monosex reached a size of $192.2 \mathrm{~g}$ within a culture period of 6 months in ponds, more than mixed-sex populations tilapia (140.3 g). [14] [29] further reported similar result, where all male tilapia showed superior growth rate over the females and mixed-sex which is in agreement with the results of the present study. They attributed this to the fact that energy is not utilized for reproduction and there exist no competition with younger fish in all male tilapia culture. However, has been registered that the tilapia of more than $200 \mathrm{~g}$ attracts premium prices in the market at national level and, it is more accepted by consumers.

The variation in weight observed in this study, might be explained by the establishment of hierarchies in feeding among the fish. Dominant individuals within a population may have consumed more food and have grown faster leaving less food for the submissive individuals, which in turn had slower growth and may have low biomass. Hierarchical interactions among fish was evidenced by the variation in size (few small and numerous large) of harvested fish following treatment. Similar results were reported by [21].

Monosex tilapia showed significantly higher weight, length, survival rate. The higher values of weight of the fish treated can be attributed to the anabolic effect of hormone to induce sex reversal in farmed tilapias [30]. In this respect, some studies reported that the anabolic effect of hormone showed an increase in individual growth of tilapia [31] [32]. Other studies reported that the higher mean weights could be attributed to the improvement of food conversion efficiency of sex-reversed fry of Oreochromis niloticus [29] [33].

Growth of individual fish was compared well with other studies. In the present study the weight growth rate was less to $1 \mathrm{~g} /$ day. [34] [35] observed individual growth of $1.2 \mathrm{~g}$ /day in hand-sexed male tilapia raised in ponds receiving high rate of fertilizers and 1.7 - $2.0 \mathrm{~g}$ /day in fertilized ponds with supplemental feeding. [36] reported growth rates of 1.7 - $1.8 \mathrm{~g} /$ day in Nile tilapia reared in out-door tanks, higher than the fish culture in this study.

A further major factor affecting the growth rates of the fish was the relative exposure to lower temperatures occurring in the latter part of the growing season. Whereas fish grew during the period of optimal temperatures early in the season (May-July, $23^{\circ} \mathrm{C}-25^{\circ} \mathrm{C}$ ), the growth rate were lowest when the ambient temperature began to decline toward the end of the culture (September-October; $22.5^{\circ} \mathrm{C}-21^{\circ} \mathrm{C}$ ).

[21] cited that the better performance of hormone-treated fish compared to untreated fish during grow-out is in accordance due to a combination of factors: faster growth of males, improved food conversion efficiency and activation of other endogenous anabolic hormones enhancing growth.

[15] mentioned that using monosex seed can control the stunting problem caused by competition for food that otherwise occur between recruits and stocked fish. Moreover, has been showed that on average, monosex fish 
grew more than $10 \%$ faster than mixed-sex fish in both ponds and cages [31]. Faster growth of monosex tilapia has been related to the lack of energy expenditure in egg production and mouth brooding by females and lower energy expenditure on courtship by males [31].

The results of the present study showed that the best weight gain was observed in monosex males as $192.2 \mathrm{~g}$, the specific growth rate (SGR) was recorded of 4.1 and the food conversion ratio (FCR) was 1.12. These values were similar to registered by [29] [37]. The commercial food presented highest values of FBW, SGR, FE and low FCR, showing that tilapia fish require a dietary protein level of $40 \%$ and $12 \%$ of lipids. This result is in agreement with the optimum $\mathrm{P} / \mathrm{E}$ ratio for optimum growth of several species of teleost fish that range from 19 to 27 [38]. Comparatively, the requirements of tilapia fish are similar to those reported in other carnivorous fishes ranging between $32 \%$ to $50 \%$ of protein and $7 \%$ to $17 \%$ of lipids such as in the fingerlings of bay snook [39].

It was observed in other experiments that fish treated at higher densities had similar total length to those treated at lower densities; thus it is apparent that the fish held at higher densities were in poorer condition, as it is mentioned by [21]. A considerable advantage of the adequate or low stocking density was the significant reduction in mortality, and then high survival, as happened in this experiment.

Monthly mortality was estimated from known numbers of fish only at the beginning of the experiment. While mortality rate was assumed constant over time, losses may have occurred mainly over some small time interval. Mortality was generally small $(<5 \%)$, so errors from this assumption should have been minor. Similar results were obtained by [34], but different to reported by [29].

The results of the present study revealed that the growth performance between all male and mixed-sex Oreochromis niloticus reared for 180 days under the same culture condition was significantly different, where the male mono-sex fish attained a larger final individual size than the mixed-sex group. [29] further reported similar result, where all male tilapia showed superior growth rate over the mixed-sex, which is in agreement with the results of the present study.

Alkaline $\mathrm{pH}$ was also found to favour tilapia growth in the concrete pond together with the conductivity and total dissolved solids. The aquatic system also showed to be productive and will support the density of population of fishes. Then, the tilapia growth was strongly influenced by the physical-chemical factors which showed the water quality to be good according to [22] [23]. Temperature, food abundance, nutrients were some of the factors that could limit fish growth in the pond, and maintenance of good water quality will be a great advantage for fish production.

Water temperature is one of the most important environmental factors affecting fish physiological responses of growth and feed utilization. Water temperature varied little between ponds for a same date, but differed significantly between months. Reports on Nile tilapia showed that the optimal temperature for growth and reproduction was between $22^{\circ} \mathrm{C}$ to $32^{\circ} \mathrm{C}$ [40] [41]. For fish increased water temperature could increase both feed intake and growth, while excessively high temperatures result in decreased growth and feed efficiency with decreased feed intake [42] [43].

Respect to the ideal DO level for tilapia culture is 4 - $5 \mathrm{mg} / \mathrm{l}$ and the present study showed higher DO values for all the ponds attributing good environment for tilapia culture. These similar results were registered by [33]. Therefore, different physic-chemical parameters of water like temperature, DO, transparency, $\mathrm{pH}$ and nutrient are generally considered to have primary importance in fish culture.

In conclusion, the present study revealed that the higher values of mean length, weight and survival rates were recorded in fish on sex reversal of Oreochromis niloticus in the environmental condition at Mexico City. It is possible that the higher survival at lower densities observed in this study was due to good water quality in the pond during the treatment period. Moreover, an alternative explanation for decreased growth could be deleterious $\mathrm{pH}$ levels caused by inorganic fertilizer addition, and the fish size could be affected by non optimal temperature too during experimental period. Use of hormone to induce sex reversal in farmed tilapias has become a common practice, and it is a simple and reliable way to produce all-male tilapia stocks, which consistently grow to a larger uniform size than mixed sex or all-female stocks. This experiment was the first of its kind, comparing the growth performance of male tilapia and mixed-sex populations in a single environment.

\section{Acknowledgements}

We thank everyone who kindly assisted in several parts of the work processing and providing measurements of 
$O$, niloticus and environmental variables. This work was supported by the Facultad de Estudios Superiores Zaragoza and DGAPA-PAPIME program (project code PE205513) of National Autonomous University of México.

\section{References}

[1] Admassu, D. (1996) The Breeding Season of Tilapia, Oreochromis niloticus L. in Lake Awassa (Ethiopian Rift Valley). Hydrobiologia, 337, 77-83. http://dx.doi.org/10.1007/BF00028508

[2] Coward, K. and Bromage, N.R. (1998) Histological Classification of Oocyte Growth and the Dynamics of Ovarian Recrudescence in Tilapia zillii. Journal of Fish Biology, 53, 285-302.

[3] Lin, Y.H., Lin, S.M. and Shiau, S.Y. (2008) Dietary Manganese Requirements of Juvenile Tilapia, Oreochromis nilotis x O.aureus. Aquaculture, 284, 207-210. http://dx.doi.org/10.1016/j.aquaculture.2008.07.049

[4] Gómez-Márquez, J.L., Peña-Mendoza, B., Salgado-Ugarte, I.H. and Guzmán-Arroyo, M. (2003) Reproductive Aspects of Oreochromis niloticus (Perciformes: Cichlidae) at Coatetelco Lake, Morelos, Mexico. Revista de Biología Tropical, 51, 221-228.

[5] Jiménez-Badillo, L. (2006) Age-Growth Models for Tilapia Oreochromis aureus (Perciformes: Cichlidae) of the Infiernillo Reservoir, Mexico and Reproductive Behavior. Revista de Biología Tropical, 54, 577-588. http://dx.doi.org/10.1016/j.aquaculture.2008.07.049

[6] Wohlfarth G.W. and Hulata, G. (1983) Applied of Tilapias. ICLARM Studies and Reviews 6. International Center for Living Aquatic Resources Management, Manila, 26 p.

[7] Yi, Y., Lin, C.K. and Diana, J.S. (1996) Influence of Nile tilapia (Oreochromis niloticus) Stocking Density on Their Growth and Yield in Cages and Ponds Containing the Cages. Aquaculture, 146, 205-215. http://dx.doi.org/10.1016/j.aquaculture.2008.07.049

[8] El-Saidy, D.M.S.D. and Gaber, M.M.A. (2005) Effect of Dietary Protein Levels and Feeding Rates on Growth Performance, Production Traits and Body Composition of Nile tilapia, Oreochromis niloticus (L.) Cultured in Concrete Tanks. Aquaculture Research, 36, 163-171. http://dx.doi.org/10.1111/j.1365-2109.2004.01201.x

[9] CONAPESCA (2012) Statistical Yearbook of Aquaculture and Fishery 2011. Dirección General de Planeación, Programación y Evaluación. Comision Nacional de Acuacultura y Pesca. Sagarpa, México.

[10] Babiker, M. and Ibrahim, H. (1979) Studies on the Biology of Reproduction in the Cichlid Tilapia nilotica (Linneo): Gonadal Maturation and Fecundity. Journal of Fish Biology, 14, 437-448. http://dx.doi.org/10.1111/j.1095-8649.1979.tb03541.x

[11] de Graaf, G.J., Galemoni, F. and Huisman, E.A. (1999) Reproductive Biology of Pond Reared Nile Tilapia, Oreochromis niloticus L. Aquaculture Research, 30, 25-33. http://dx.doi.org/10.1046/j.1365-2109.1999.00295.x

[12] Lèveque, C. (2002) Out of Africa: The Success Story of Tilapias. Environmental Biology of Fishes, 64, 461-464. http://dx.doi.org/10.1023/A:1016190529697

[13] Lahav, M. and Lahav, E. (1990) The Development of All-Male Tilapia Hybrids in Nir David. Bamidgeh, 42, 58-61.

[14] Pandian, T.J. and Varadaraj, K. (1990) Techniques to Produce 100\% Male Tilapia. NAGA, The ICLARM Quarterly, 7, 3-5.

[15] Mair, G.C. and Little, D.C. (1991) Population Control in Farmed Tilapias. NAGA, The ICLARM Quarterly, 4, 8-13.

[16] Angienda, P.O., Aketch, B.O. and Waindi, E.N. (2010) Development of All-Male Fingerlings by Heat Treatment and the Genetic Mechanism of Heat Induced Sex Determination in Nile Tilapia (Oreochromis niloticus L.). International Journal of Biological and Life Sciences, 6, 38-43.

[17] El-Greisy, Z.A. and El-Gamal, A.E. (2012) Monosex Production of Tilapia, Oreochromis niloticus Using Different Doses of $17 \alpha$-Methyltestosterone with Respect to the Degree of Sex Stability after One Year of Treatment. The Egyptian Journal of Aquatic Research, 38, 59-66. http://dx.doi.org/10.1016/j.ejar.2012.08.005

[18] Bushan, S.C. and Banerjee, S. (2009) Culture of Monosex Nile Tilapia under Different Traditional and Non-Traditional Methods in India. World Journal of Fish and Marine Sciences, 1, 212-217.

[19] Buddle, C.R. (1984) Androgen-Induced Sex-Inversion of Oreochromis (Trewavas) Hybrid Fry Stocked into Cages Standing in an Earthen Pond. Aquaculture, 40, 233-239. http://dx.doi.org/10.1016/0044-8486(84)90190-X

[20] Baltazar, G.P.M. (2009) Culture of Tilapia in Peru. Infopesca Internacional, 40, 21-26.

[21] Vera Cruz, E.M. and Mairb, G.C. (1994) Conditions for Effective Androgen Sex Reversal in Oreochromis niloticus (L.). Aquaculture, 122, 237-248. http://dx.doi.org/10.1016/0044-8486(94)90513-4

[22] APHA, AWWA and WPCF (1992) Standard Methods for Examination of Water and Sewage and Wastewater. 18th Edition, EEUU, Washington DC. 
[23] Arredondo, F.J.L. and Ponce, J.T.P. (1998) Water Quality in Aquaculture: Concepts and Applications. AGT Editor, S.A. Mexico.

[24] Nguyen, C.D. and Little, D.C. (2000) The Culture Performance of Monosex and Mixed-Sex New-Season and Overwintered Fry in Three Strains of Nile Tilapia Oreochromis niloticus in Northern Vietnam. Aquaculture, 184, 221-231. http://dx.doi.org/10.1016/S0044-8486(99)00329-4

[25] Ergün, S., Guroy, D., Tekesoglu, H., Guroy, B., Celic, I., Tekinay, A.A. and Bulut, M. (2010) Optimum Dietary Protein Level for Blue Streak Hap, Labidochromis caeruleus. Turkish Journal of Fisheries and Aquatic Sciences, 10, 2731.

[26] Pauly, D. (1984) Fish Population Dynamics in Tropical Waters: A Manual for Use with Programmable Calculators. International Center for Living Aquatic Resources Management, Studies and Reviews 8, Manila.

[27] Steel, D.G.R. and Torrie, J.H. (1981) Principles and Procedures of Statistics. A Biometrical Approach. McGraw-Hill, Nueva York.

[28] Marques, D.S. and Ma, J. (2004) Probability and Statistics for Chemical Biological Sciences. National Autonomous University of Mexico, Campus Zaragoza, México, D.F.

[29] Dagne, A., Degefu, F. and Lakew, A. (2013) Comparative Growth Performance of Mono-Sex and Mixed-Sex Nile Tilapia (Oreochromis niloticus L.) in Pond Culture System at Sebeta, Ethiopian. International Journal of Aquaculture, 3, 30-34.

[30] Jo, J.Y., Smitherman, R.O. and Tave, D. (1995) Effect of Six Levels of Dietary $17 \alpha$-Methyltestosterone on Sex-Reversal and Growth of Oreochromis aureus (Steindachner) and Oreochromis niloticus (Linnaeus). Journal of Aquaculture, 8, 77-83.

[31] Mair, G.C., Abucay, J.S., Beardmore, J.A. and Skibinski, D.O.F. (1995) Growth Performance Trials of Genetically Male Tilapia (G17 $\alpha$-MT) Derived from YY-Males in Oreochromis niloticus L.: On Station Compositions with Mixed Sex and Sex Reversed Male Populations. Aquaculture, 137, 313-332. http://dx.doi.org/10.1016/0044-8486(95)01110-2

[32] Dan, N.C. and Little, D.C. (2000) The Culture Performance of Monosex and Mixed-Sex New-Season and Overwintered Fry in Three Strains of Nile Tilapia (Oreochromis niloticus ) in Northern Vietnam. Aquaculture, 10, 32-34.

[33] Chakraborty, S.B. and Banerjee, S. (2010) Comparative Growth Performance of Mixed-Sex and Monosex Nile Tilapia Population in Freshwater Cage Culture System under Indian Perspective. International Journal of Biology, 2, 44-50. http://dx.doi.org/10.5539/ijb.v2n1p44

[34] Diana, J.S., Lin, C.K. and Schneeberger, P.J. (1991) Relationships among Nutrient Inputs, Water Nutrient Concentrations, Primary Production, and Yield of Oreochromis niloticus in Ponds. Aquaculture, 92, 323-341. http://dx.doi.org/10.1016/0044-8486(91)90038-9

[35] Diana, J.S., Lin, C.K. and Jaiyen, K. (1994) Supplemental Feeding of Tilapia in Fertilized Ponds. Journal of World Aquaculture Society, 25, 497-506. http://dx.doi.org/10.1111/j.1749-7345.1994.tb00818.x

[36] Siddiqui, A.Q., Howlader, M.S. and Adam, A.B. (1989) Culture of Nile Tilapia, Oreochromis niloticus (L.) at Three Stocking Densities in Outdoor Concrete Tanks Using Drainage Water. Aquaculture and Fisheries Management, 20, 49-57.

[37] Ahmed, G.U., Sultana, N., Shamsuddin, M. and Hossain, M.B. (2013) Growth and Production Performance of Monosex Tilapia (Oreochromis niloticus) Fed with Homemade Feed in Earthen Mini Ponds. Pakistan Journal Biology Science, 16, 1781-1785. http://dx.doi.org/10.3923/pjbs.2013.1781.1785

[38] Nutritional Research Council (NRC) (1993) Nutrient Requirements of Fish. National Academy of Press, Washington DC.

[39] Arredondo-Figueroa, J.L., Matsumoto-Soulé, J.J., Ponce-Palafox, J.T., Shirai-Matsumoto, K. and Gómez-Márquez, J.L. (2012) Effects of Protein and Lipids on Growth Performance, Feed Efficiency and Survival Rate in Fingerlings of Bay Snook (Petenia splendida). International Journal of Animal and Veterinary Advances, 4, 204-213.

[40] Morales, D.A. (1991) The Tilapia in México. Biology, Culture and Fisheries. AG Editor, S.A. Mexico.

[41] El-Sayed, A.F.M. and Kawanna, M. (2008) Optimum Water Temperature Boosts the Growth Performance of Nile Tilapia (Oreochromis niloticus) Fry Reared in a Recycling System. Aquaculture Research, 39, 670-672. http://dx.doi.org/10.1111/j.1365-2109.2008.01915.x

[42] Handeland, S.O., Imsland, A.K. and Stefansson, S.O. (2008) The Effect of Temperature and Fish Size on Growth, Feed Intake, Food Conversion Efficiency and Stomach Evacuation Rate of Atlantic Salmon Post-Smolts. Aquaculture, 283, 36-42. http://dx.doi.org/10.1016/j.aquaculture.2008.06.042

[43] Xie, S., Zheng, K., Chen, J., Zhang, Z., Zhu, X. and Yang, Y. (2011) Effect of Water Temperature on Energy Budget of Nile Tilapia Oreochromis niloticus. Aquaculture Nutrition, 17, e583-e690.

http://dx.doi.org/10.1111/j.1365-2095.2010.00827.x 
Scientific Research Publishing (SCIRP) is one of the largest Open Access journal publishers. It is currently publishing more than 200 open access, online, peer-reviewed journals covering a wide range of academic disciplines. SCIRP serves the worldwide academic communities and contributes to the progress and application of science with its publication.

Other selected journals from SCIRP are listed as below. Submit your manuscript to us via either submit@scirp.org or Online Submission Portal.
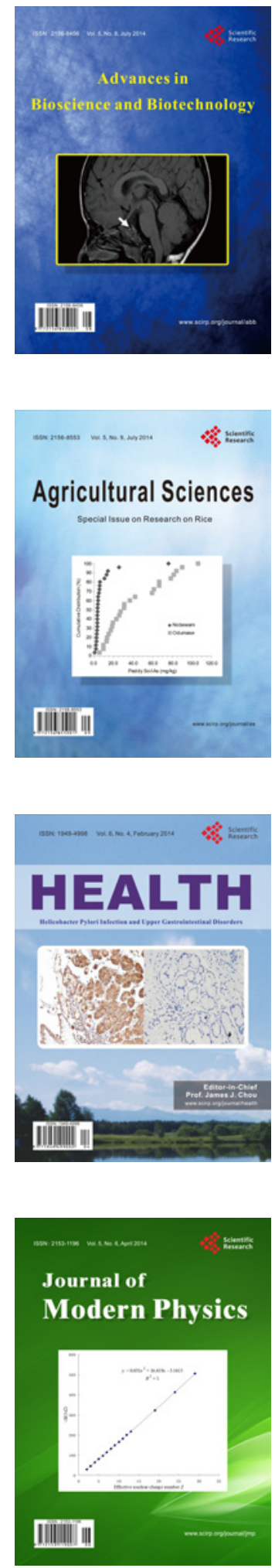
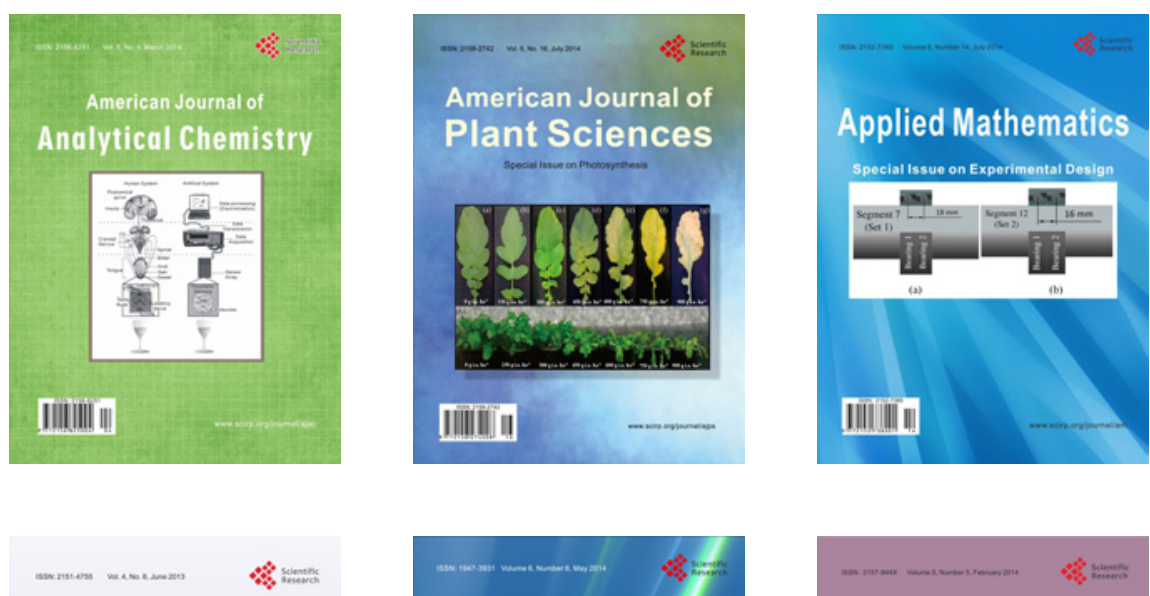

Creative Education
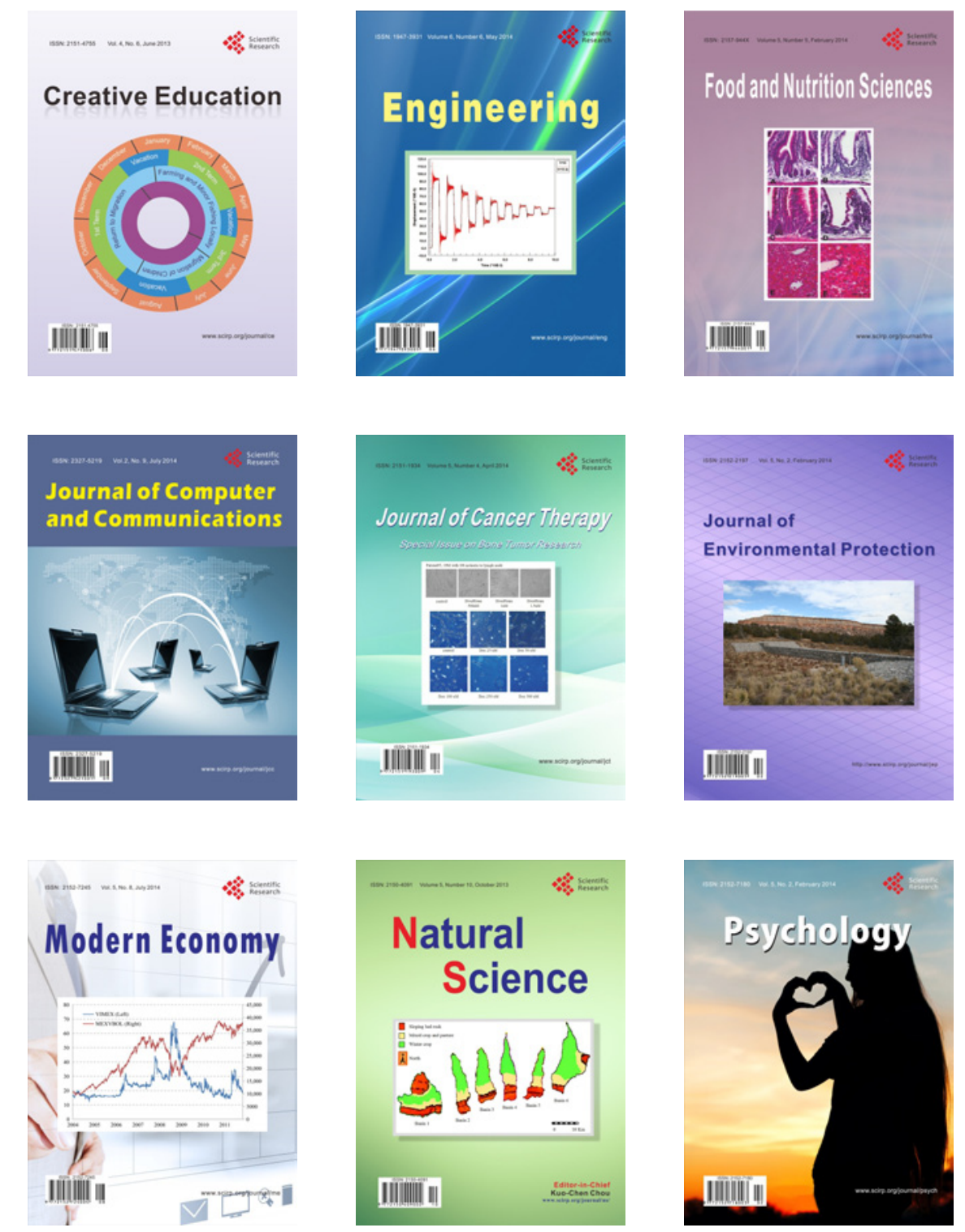